\title{
Rifted Margins: State of the Art and Future Challenges
}

\section{Gwenn Peron-Pinvidic ${ }^{1 *}$, Gianreto Manatschal2 and the "IMAGinING RIFTING" Workshop Participants'}

${ }^{1}$ Geological Survey of Norway (NGU), Trondheim, Norway, ${ }^{2}$ Institut de Geologie, University of Strasbourg, Strasbourg, France

Improvements in seismic imaging, computing capabilities, and analytical methods, as well as a number of industry deep-water wells sampling distal offshore settings, have underpinned new concepts for rifted margin evolution developed in the last two decades; these mark significant progress in our understanding of extensional systems. For example, the tectonic, sedimentary, and magmatic processes linked to the formation of rifted margins have been overhauled, giving rise to more quantitative approaches and new concepts. However, these processes cannot be understood in isolation, requiring consideration of the continuum in which inheritance and physical processes are integrated within a plate tectonic framework. The major progress and fundamental developments of past research in rifted margins have been made hand-inhand with other domains of Earth Sciences and have fundamental implications for the understanding of key geological systems such as active rifts, the ocean lithosphere, subduction zones, and collisional orogens. The "IMAGinING RIFTING" workshop, organized in Pontresina-Switzerland in September 2017, gathered researchers from all disciplines working on rifts and rifted margins, and included participants from academia and industry. This contribution summarizes the workshop discussions, in addition to outlining our state-of-the-art knowledge of rifted margins. We highlight future challenges in unraveling the processes and conditions under which these extensional systems form and, ultimately, how tectonic plates rupture and new oceans are born. Our aims here are to provide a framework for future research endeavors and to promote collaboration not only within the rift and rifted margins communities, but across other Earth Science disciplines.

Keywords: rifted margin, tectonic/sedimentation, sedimentary basin, orogen architecture, subduction

\section{WHERE DO WE COME FROM? A HISTORICAL PERSPECTIVE}

Rifted margins are the result of primary processes in plate tectonic theory that include extension within a continent, and the eventual rupture of continental lithosphere leading to the formation of new plate boundaries and oceanic domains. Although rifting is a first-order plate tectonic process, the geological and geophysical characterization of basement lithology and geometries, basin stratigraphic architecture and magmatic products continues to be debated. Such research has significant broader application as rifted margins include the Earth's most voluminous sediment accumulations, host important energy and natural resources, and are a rich archive of global environmental and climate changes (e.g., see http://geoprism.org, http://iodp.org). 
Early studies on rifted margins focused on the proximal domains in shallow water and on intracontinental rift basins, with data acquisition concentrating on the sedimentary infill down to basement in areas prospective for hydrocarbons (e.g., Levell et al., 2010). Little was known about the structure of the more distal settings or deeper crustal configuration, mainly due to the limited resolving power of the imaging technology available at that time. Consequently, models applied to explain the formation of rifted margins assumed that the processes observed at continental rifts, described by either pure and/or simple shear deformation mechanisms (McKenzie, 1978; Wernicke, 1985), could also explain the formation of rifted margins at larger scales (Figure 1). Early studies, for example, along the French Armorican margin produced viable predictive models of rift history (Le Pichon and Sibuet, 1981). Although such models could partly explain the early evolution of rifted margins, including the formation of sedimentary basins and the addition of extension-related melt (i.e., magma), they were unable to predict the evolution of more mature rift systems approaching lithospheric breakup.

The discovery of unexpected offshore structural settings, such as wide zones of exhumed subcontinental mantle and large offset normal faults (Boillot et al., 1980), set the stage for the subsequent development of new concepts and approaches (Whitmarsh et al., 2001). Expeditions funded by international science bodies such as DSDP (Deep Sea Drilling Project), ODP (Ocean Drilling Project) and IODP (International Ocean Drilling Project), together with improved technology and onshore analog studies have, over the last three decades, provided the community with new observations that forced a revision of these primary models. While the Iberia margin became the archetype of a non-volcanic margin (Whitmarsh et al., 2001), the NorwegianGreenland Sea margins became the archetypal volcanic margins (Eldholm et al., 1989), based on the contrasting magmatic budget identified in their distal settings. Later investigations, however, showed that this 2-fold division may have been overly simplistic (Mutter, 1993); non-volcanic margins were shown not to exist (Muntener et al., 2010), while the magmatic budget of volcanic margins may have been overestimated (van Wijk et al., 2004). More recent studies have therefore used the more flexible terms "magma-poor" and "magma-rich," and propose a full spectrum of margins between these end members (e.g., Franke, 2013; Figure 1). With access to newer and higher-resolution geophysical datasets, coupled with lithological and thermal data from borehole drilling, new concepts and models emerged, and the terminology used to describe margins evolved in parallel. These include morphological terms (e.g., platform, terrace, taper break, marginal high), rift domain names (necking, transitional, ocean-continent transition, zone of exhumed continental mantle, ocean-continent boundary) and terms referring to geological processes (stretching, thinning, exhumation) (e.g., Lister et al., 1991; Whitmarsh et al., 2001; Lavier and Manatschal, 2006; Frizon de Lamotte et al., 2015; Figure 1). While the new terms are not yet fully defined, and indeed are still debated, old terms such as syn-rift, breakup and breakup unconformity are now considered inadequate to describe complex new observations. It is suggested that the continued use of such terms can result in ambiguity when describing rifted margins and their evolution.

\section{WHERE ARE WE?}

Over the last decade, deep crustal seismic reflection data, collected during hydrocarbon exploration efforts, were acquired across a number of rifts and rifted margins, with additional well and seismic data becoming publicly available from governmentfunded agencies and research institutions. Syntheses of these data showed that comparable architectural features could be found on many margins worldwide (Reston, 2009) including, for example the Great Australian Bight (Ball et al., 2013), the South China Sea (Yang et al., 2018), the Gulf of Aden (Autin et al., 2010), the conjugate South Atlantic margins (Unternehr et al., 2010; Mohriak and Leroy, 2013; Stica et al., 2014; Clerc et al., 2015), and the Norwegian and Greenland margins (Faleide et al., 2010; Osmundsen et al., 2016). Onshore analogs of fossil margins preserved in collisional orogens, together with drill hole data, enabled the translation of some of the seismic interpretations made at distal rifted margins (Andersen et al., 2012; Masini et al., 2012). Here, the architectural similarities (i.e., partitioning of the extensional systems into distinct structural domains) can be interpreted to reflect a commonality of processes with regards to rifts and rifted margin formation (e.g., Franke, 2013; Peron-Pinvidic et al., 2013).

A consensus has thus been reached that rifting is fundamentally multiphase and results from the interaction of crustal and mantle processes. A significant knowledge evolution has not only occurred in our way of describing the strain evolution of rifted margins, but also in our understanding of the way that deformation is coupled with magmatic, thermal, and isostatic processes. The recent observations have resulted in revised definitions and new terminology that led to the development of refined rift scenarios (e.g., multiphase, propagation, sequential, migration; Reston, 2005; Lavier and Manatschal, 2006; Ranero and Perez-Gussinye, 2010; Huismans and Beaumont, 2011; Figure 1).

Several key parameters strongly influence rift evolution and the final geometry of rifted margins: lithospheric thermal state, compositional variations in the crust and mantle, the presence of fluids (siliceous and aqueous), and the temporal and spatial variations in the causal strain rate. These parameters all serve to control the rheology of the extending lithosphere (e.g., PérezGussinyé et al., 2006; Rupke et al., 2013; Jammes et al., 2015). Other parameters include: rift obliquity, structural inheritance, and sedimentary and magmatic input during rifting (e.g., Burov and Poliakov, 2001; Bialas et al., 2010; Jeanniot and Buiter, 2018). The modeling techniques available today allow us to explore the impact of these parameters on rift evolution (e.g., Corti et al., 2003; Huismans and Beaumont, 2007; RegenauerLieb et al., 2008; Heine et al., 2013; Brune et al., 2014; Zwaan et al., 2018). More recently, a new generation of models have provided more realistic descriptions of the strain distribution in 3D, and of the tectonic, magmatic, isostatic, and thermal evolution of rifted margins (e.g., Brune et al., 2017a; Ros et al., 2017; Le Pourhiet et al., 2018). Naliboff et al. (2017), for example, presented numerical models constraining intricate fault activity through time at the margin scale with activation, de-activation and re-activation of various fault segments; the model results 


\section{RESEARCH IN RIFTS \& RIFTED MARGINS EVOLUTION OF CONCEPTS}

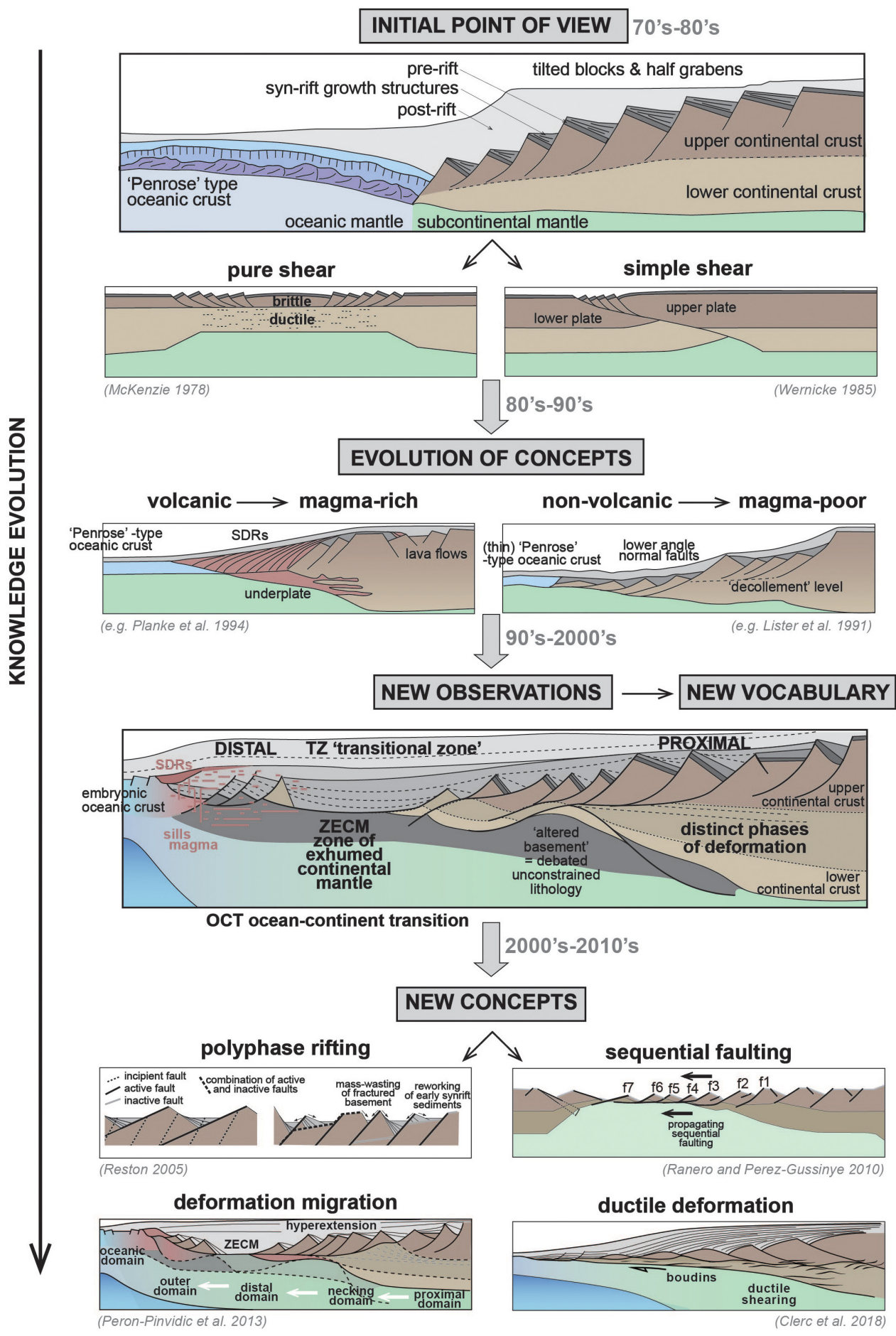

FIGURE 1 | Schematic representation of the significant progress of knowledge operated by the rifted margin community these last decades, from top (initial point of view from the 70's) to bottom (new concepts with illustration of recent models) The initial models attempting to represent rifted margins envisaged a continental crust gradually thinned oceanward and juxtaposed to a normal three-layers -type oceanic crust. Thanks to improvements in offshore imaging and modeling techniques, rifted margins are not examined within an end-member classification (volcanic/non-volcanic) anymore, but in light of a gradual change in processes (new observations - new vocabulary). 
illustrate the complexity of the final tectonic structures and of their temporal and spatial evolution.

\section{WHY SHOULD OTHER COMMUNITIES CARE ABOUT RIFTS AND RIFTED MARGINS?}

Classically, rifted margin research has been linked to applied problems in hydrocarbon exploration. While the hydrocarbon industry has undoubtedly been the main driver behind major improvements in imaging techniques and new data acquisition, the sedimentary archives of passive margins have proven valuable for interdisciplinary research beyond the petroleum industry and rifted margins communities. This archive can help address some of the most pressing environmental issues presently faced by humanity. These include, for example, an understanding of rapid climate change and the link between slow and fast greenhouse gas cycles (methane and $\mathrm{CO}_{2}$ ), such as the Paleocene-Eocene Thermal Maximum (PETM) that is being connected to the formation of the conjugate North Atlantic Volcanic margins ca. $55 \mathrm{Ma}$ (ECORDS Magellan Workshop) ${ }^{1}$. Recently, magma production during rifting and breakup has also been related to massive $\mathrm{CO}_{2}$ production, which could explain natural excursions of methane and $\mathrm{CO}_{2}$ in Earth history (e.g., Svensen et al., 2004; Brune et al., 2017b). Similarly, the discovery of exhumed mantle domains and related serpentinization can account for substantial mass transfer of elements from the mantle into the hydrosphere, as well as the production of high volumes of methane and other gases (Pinto et al., 2017).

The formation of oceanic gateways during continental breakup exert a strong influence on the circulation of oceanic currents, and hence on the evolution and distribution of life (e.g., IODP Expedition 388)2 . Alternatively, the restriction of vast basins during rifting has resulted in the formation of giant evaporite provinces favoring the preservation of organic material, as observed in many hyperextended rifted margins (e.g., South Atlantic, Gulf of Mexico, Central Atlantic) (Rowan, 2014). Thus, formation of rifted margins, in particular during the stages preceding breakup, can have a fundamental impact on the paleoclimate, oceanography, and the redistribution of elements in the Earth system.

For various reasons, including accessibility, assessment of earthquakes and volcanic risks, the geodynamic community has been more focused in understanding the evolution of mid ocean ridges, subduction zones and mountain belts than rifted margins. The fact that present-day passive margins are not tectonically active makes it more difficult to image and understand the processes that are at the origin of their formation. However, neither the onset of seafloor spreading, nor the formation of subduction zones and collisional mountain belts can be investigated without understanding rifted margins. Today it is commonly accepted that the internal architecture of collisional orogens is partly controlled by rift inheritance (e.g., Jourdon

${ }^{1}$ http://www.ecord.org/science/magellanplus/

${ }^{2}$ https://iodp.tamu.edu/scienceops/expeditions/equatorial_atlantic_gateway.html et al., 2019), but little is known about how margin architecture may control the onset of subduction, or the distribution of compressional strain in orogens, which in turn may change our understanding of the seismic cycle in orogens.

\section{WHERE ARE WE GOING?}

The global role of the main parameters (thermal state, composition, opening rates), as well as inheritance (compositional, structural, and thermal), influencing rift evolution and final structure of rifted margins are now better understood following decades of research. However, the interaction and feedback between these parameters and inheritance is still poorly constrained.

The workshop identified five key themes in rifted margin research that we consider high priority targets. Across all themes, data coverage, uncertainty, bias, scale, and timing were identified as key components. The themes were:

\section{Rheology}

At magma-poor margins key issues relate to the role of different rheologies (brittle vs. ductile) and the processes controlling the rheological evolution, including thermal state, depth, fluids, and strain rates. At magma-rich margins, the key issues relate to timing, distribution and volume of magma, its relation to deformation, and the processes of emplacement (e.g., Norcliffe et al., 2018). Answering these questions requires a careful investigation of the margins in order to adequately capture the role of each process during rifting and subsequent breakup.

\section{Inheritance}

The role of inheritance in controlling the evolution of rifted margins remains poorly constrained. Most present-day rifted margins were built upon earlier continental collision zones. Progress has been made in defining different types of orogenic inheritance, including structural, thermal, and compositional inheritance (Manatschal et al., 2014; Gouiza and Paton, 2019). However, it remains difficult to characterize the different types of inheritance on the scale of rifted margins, and the way such inheritance is related to rift-induced processes such as, for instance, serpentinization and magmatism.

\section{Faults}

Normal faults facilitate extension and eventual rupture of continental crust. Although we have a relatively robust understanding of fault populations and their growth during the early, low-strain (i.e., low- $\beta$ ) phase of rifted margin development (Cowie et al., 2005; Rotevatn et al., 2018), the precise way in which pre-existing structures, inherited from earlier phases of extension of plate collision, control the geometry and kinematics of subsequent rift-related faults remains unclear (Phillips et al., 2016). We know remarkably little about fault dynamics during the latter stages of so-called "hyperextension," immediately prior to plate rupture. During this time, fault growth may be impacted by interactions with melt generated by lower crustal and mantle melting, with 
polyphase faulting, and exhumation of mantle, arguably leading to extremely complex fault patterns (Reston, 2005). Such fault geometry is challenging to resolve, even with high-quality seismic reflection data $(\mathrm{McD}$ ermott and Reston, 2015). These challenges and complexities aside, understanding the growth of normal faults during extension is critical, with slip on these structures triggering large, potential hazardous earthquakes, and related deformation playing a major role in the formation of economically important hydrocarbon accumulations.

\section{Stratigraphy}

The stratigraphic architecture of rifted margins has long been explained within the framework of classical rift models, with syn-tectonic packages showing growth structures in fault bounded half-graben basins (Gawthorpe and Leeder, 2000). Modern concepts now include polyphase (Reston, 2005), re-activation and de-activation of faults segments (Naliboff et al., 2017), in- and out-of sequence fault-systems (Gillard et al., 2015). These previously unidentified structural contexts imply specific depositional environments for the sediments. Therefore, the architecture and composition of the different stratigraphic sequences differ from the classical models, and terms such as synrift, post-rift, and breakup unconformity need to be revised (Masini et al., 2013).

\section{Kinematics}

When compared to oceanic spreading, the process of continental extension lacks robust temporal and spatial markers such as magnetic isochrons and oceanic fracture zones. In some rift systems, such as the South Atlantic, the kinematics of prebreakup extension (Heine et al., 2013) are better constrained than in others, allowing for quantitative linking of margin evolution and plate motions (Brune et al., 2014). Such an integrated kinematic framework provides an avenue to explore links and dependencies between rheology, inheritance, faulting, and stratigraphy, by means of forward and inverse modeling. With the availability of integration platforms that can bridge the classic scale gaps between plate tectonic and basin scale modeling, such as GPlates (Boyden et al., 2011), significant improvements can be made to incorporate observations from other disciplines with continental deformation in a plate tectonic framework. This will ultimately allow us to explore driving forces, links with deep Earth dynamics, paleo-oceanography, gateway evolution, and source-tosink systems.

\section{Mantle}

Nearly four decades have passed since the discovery of peridotite rocks in the distal settings of rifted margins (Boillot et al., 1980). The presence of wide zones of exhumed mantle has been confirmed and mapped at several rifted margins, both onshore and offshore. Drilling, sampling and analyses of some occurrences permitted the characterization of these mantle exposures (e.g., Picazo et al., 2016). It has been proposed that the mantle lithosphere plays a major role in rifted margin evolution, influencing the structural, rheological, and magmatic activities (Chenin et al., 2018). However, these remain globally unconstrained and further research on this topic is needed.

The definition of the above research themes led the workshop attendees to outline five key strategies for future research:

(1) Increase the spatial and temporal resolution of our datasets in order to study rifted margins in greater detail; by doing this, we can better understand the geometry and tectonostratigraphic development, both onshore and offshore.

(2) Develop multi-disciplinary/inter-disciplinary projects in order to link our own disciplines (multi-disciplinary), but also to engage other distinct communities (interdisciplinary) (e.g., mid-ocean ridges, orogens, subduction).

(3) Plan additional sampling of sedimentary and basement rocks. In particular, sampling of distal margins is needed in order to strengthen the existing datasets. Excepting a limited number of cases (Iberia-Newfoundland, Red Sea, Southern Australia, South China Sea), basement samples from distal margins are not available to discriminate and correctly interpret the notoriously nonunique interpretations of the associated geophysical datasets. In order to obtain access to such samples, new IODP proposals are necessary. We will target the already well-constrained systems (e.g., Iberia, South China Sea, Norway) in order to achieve a balance between scientific challenges, accessibility and representativity. Additionally, a cheaper, but more indirect way to obtain critical data is to work on fossil margin analogs exposed in collisional orogens, or to get access to well and geophysical data from the hydrocarbon industry.

(4) Open access data: Vast amounts of high-quality seismic reflection data remain confidential property of energy companies; making these crucial data (or part of) public would certainly enhance understanding of rifted margins. Therefore, promoting open access subsurface databases, curated by professional data administrators, is crucial for the academic community. The use of similar formats and open domain software may facilitate scientific exchange and foster collaborations.

(5) Training: Finally, updating what is taught about rifted margins at undergraduate level and training the next generation of young future researchers is fundamental. Therefore, it was decided that working on a proposal for an European Training Network (EU funding) is a priority.

\section{AUTHOR CONTRIBUTIONS}

GP-P and GM have written the document and the workshop participants greatly helped improving the text with corrections, suggestions and comments. 


\section{REFERENCES}

Andersen, T. B., Corfu, F., Labrousse, L., and Osmundsen, P.-T. (2012). Evidence for hyperextension along the pre-Caledonian margin of Baltica. J. Geol. Soc. 169, 601-612. doi: 10.1144/0016-76492012-76492011

Autin, J., Leroy, S., Beslier, M. O., d'Acremont, E., Razin, P., Ribodetti, A., et al. (2010). Continental break-up history of a deep magma-poor margin based on seismic reflection data (northeastern Gulf of Aden margin, offshore Oman). Geophys. J. Int. 180, 501-519. doi: 10.1111/j.1365-246X.2009.04424.x

Ball, P., Eagles, G., Ebinger, C., McClay, K., and Totterdell, J. (2013). The spatial and temporal evolution of strain during the separation of Australia and Antarctica. Geochem. Geophys. Geosyst. 14, 2771-2799. doi: 10.1002/ggge.20160

Bialas, R. W., Buck, W. R., and Qin, R. (2010). How much magma is required to rift a continent? Earth Planet. Sci. Lett. 292, 68-78. doi: 10.1016/j.epsl.2010.01.021

Boillot, G., Grimaud, S., Mauffret, A., Mougenot, D., Kornprobst, J., MergoilDaniel, J., et al. (1980). Ocean-continent boundary off the Iberian margin: a serpentinite diapir west of the Galicia Bank. Earth Planet. Sci. Lett. 48, 23-34. doi: 10.1016/0012-821X(80)90166-90161

Boyden, J. A., Müller, R. D., Gurnis, M., Torsvik, T. H., Clark, J. A., Turner, M., et al. (2011). "Next-generation plate-tectonic reconstructions using GPlates" in Geoinformatics: Cyberinfrastructure for the Solid Earth Sciences, eds G. R. Keller, and C. Baru (Cambridge: Cambridge University Press).

Brune, S., Heine, C., Clift, P. D., and Pérez-Gussinyé, M. (2017a). Rifted margin architecture and crustal rheology: reviewing iberia-newfoundland, central South Atlantic, and South China Sea. Mar. Pet. Geol. 79, 257-281. doi: 10.1016/ j.marpetgeo.2016.10.018

Brune, S., Williams, S. E., and Müller, R. D. (2017b). Potential links between continental rifting, $\mathrm{CO} 2$ degassing and climate change through time. Nat. Geosci. 10, 941-946. doi: 10.1038/s41561-017-0003-6

Brune, S., Heine, C., Pérez-Gussinyé, M., and Sobolev, S. V. (2014). Rift migration explains continental margin asymmetry and crustal hyper-extension. Nat. Commun. 5:4014. doi: 10.1038/ncomms5014

Burov, E., and Poliakov, A. (2001). Erosion and rheology controls on synrift and postrift evolution: verifying old and new ideas using a fully coupled numerical model. J. Geophys. Res. 106, 16461-16481. doi: 10.1029/2001jb00 0433

Chenin, P., Picazo, S., Jammes, S., Manatschal, G., Müntener, O., and Karner, G. (2018). Potential Role of Lithospheric Mantle Composition in the Wilson Cycle: a North Atlantic Perspective. London: Geological Society, doi: 10.1144/sp470.10

Clerc, C., Jolivet, L., and Ringenbach, J.-C. (2015). Ductile extensional shear zones in the lower crust of a passive margin. Earth Planet. Sci. Lett. 431, 1-7. doi: 10.1016/j.epsl.2015.08.038

Corti, G., Bonini, M., Conticelli, S., Innocenti, F., Manetti, P., and Sokoutis, D. (2003). Analogue modelling of continental extension: a review focused on the relations between the patterns of deformation and the presence of magma. Earth Sci. Rev. 63, 169-247. doi: 10.1016/s0012-8252(03)00035-7

Cowie, P. A., Underhill, J. R., Behn, M. D., Lin, J., and Gill, C. E. (2005). Spatio-temporal evolution of strain accumulation derived from multi-scale observations of Late Jurassic rifting in the northern North Sea: a critical test of models for lithospheric extension. Earth Planet. Sci. Lett. 234, 401-419. doi: 10.1016/j.epsl.2005.01.039

Eldholm, O., Thiede, J., and Taylor, B. (1989). "Evolution of the Vøring volcanic margin," in Proceedings of the Ocean Drilling Program, Scientific Results, Vol. 104, eds O. Eldholm, J. Thiede, and E. Taylor (College Sation, TX: Ocean Drilling Program), 1033-1065.

Faleide, J. I., Bjørlykke, K., and Gabrielsen, R. H. (2010). "Geology of the Norwegian Continental Shelf," in Petroleum Geoscience: From Sedimentary Environments to Rock Physics, ed. K. Bjørlykke (New York, NY: Springer), 467-499. doi: 10.1007/978-3-642-02332-3_22

Franke, D. (2013). Rifting, lithosphere breakup and volcanism: comparison of magma-poor and volcanic rifted margins. Mar. Pet. Geol. 43, 63-87. doi: 10. 1016/j.marpetgeo.2012.11.003

Frizon de Lamotte, D., Fourdan, B., Leleu, S., Leparmentier, F., and Clarens, P. (2015). Style of rifting and the stages of Pangea breakup. Tectonics 34, 1009-1029. doi: 10.1002/2014TC003760

Gawthorpe, R. L., and Leeder, M. R. (2000). Tectono-sedimentary evolution of active extensional basins. Basin Res. 12, 195-218. doi: 10.1111/j.1365-2117. 2000.00121.x
Gillard, M., Autin, J., Manatschal, G., Sauter, D., Munschy, M., and Schaming, M. (2015). Tectonomagmatic evolution of the final stages of rifting along the deep conjugate Australian-Antarctic magma-poor rifted margins: constraints from seismic observations. Tectonics 34, 753-783. doi: 10.1002/2015tc00 3850

Gouiza, M., and Paton, D. A. (2019). The role of inherited lithospheric heterogeneities in defining the crustal architecture of rifted margins and the magmatic budget during continental breakup. Geochem. Geophys. Geosyst. 20, 1836-1853. doi: 10.1029/2018gc007808

Heine, C., Zoethout, J., and Muller, D. (2013). Kinematics of the South Atlantic rift. Solid Earth 4, 215-253. doi: 10.5194/se-4-215-2013

Huismans, R., and Beaumont, C. (2011). Depth-dependent extension, two-stage breakup and cratonic underplating at rifted margins. Nature 473, 74-78. doi: 10.1038 /nature09988

Huismans, R. S., and Beaumont, C. (2007). Roles of Lithospheric Strain Softening and Heterogeneity in Determining the Geometry of Rifts and Continental Margins. London: Geological Society, 111-138. doi: 10.1144/SP282.6

Jammes, S., Lavier, L. L., and Reber, J. E. (2015). Localization and delocalization of deformation in a bimineralic material. J. Geophys. Res. 120, 3649-3663. doi: 10.1002/2015JB011890

Jeanniot, L., and Buiter, S. J. H. (2018). A quantitative analysis of transtensional margin width. Earth Planet. Sci. Lett. 491, 95-108. doi: 10.1016/j.epsl.2018. 03.003

Jourdon, A., LePourhiet, L., Mouthereau, F., and Masinic, E. (2019). Role of rift maturity on the architecture and shortening distribution in mountain belts. EPSL 512, 89-99. doi: 10.1016/j.epsl.2019.01.057

Lavier, L. L., and Manatschal, G. (2006). A mechanism to thin the continental lithosphere at magma-poor margins. Nature 440, 324-328. doi: 10.1038/ nature 04608

Le Pichon, X., and Sibuet, J. C. (1981). Passive margins: a model of formation. JGR 86, 3708-3720. doi: 10.1029/JB086iB05p03708

Le Pourhiet, L., Chamot-Rooke, N., Delescluse, M., May, D. A., Watremez, L., and Pubellier, M. (2018). Continental break-up of the South China Sea stalled by far-field compression. Nat. Geosci. 11, 605-609. doi: 10.1038/s41561-018-017 8-175

Levell, B., Argent, J., Doré, A. G., and Fraser, S. (2010). “Passive margins: overview," in Petroleum Geology: From Mature Basins to New Frontiers - Proceedings of the 7th Petroleum Geology Conference, Vol. 7, eds B. A. Vining and S. C. Pickering (London: Geological Society), 823-830. doi: 10.1144/0070823

Lister, G. S., Etheridge, M. A., and Symonds, P. A. (1991). Detachment models for the formation of passive continental margins. Tectonics 10, 1038-1064. doi: 10.1029/90tc01007

Manatschal, G., Lavier, L., and Chenin, P. (2014). The role of inheritance in structuring hyperextended rift systems: some considerations based on observations and numerical modeling. Gondwana Res. 27, 140-164. doi: 10. 1016/j.gr.2014.08.006

Masini, E., Manatschal, G., and Mohn, G. (2013). The alpine tethys rifted margins: reconciling old and new ideas to understand the stratigraphic architecture of magma-poor rifted margins. Sedimentology 60, 174-196. doi: 10.1111/sed. 12017

Masini, E., Manatschal, G., Mohn, G., and Unternehr, P. (2012). Anatomy and tectono-sedimentary evolution of a rift-related detachment system: the example of the Err detachment (central Alps, SE Switzerland). Geol. Soc. Am. Bull. 124, 1535-1551. doi: 10.1130/b30557.1

McDermott, K., and Reston, T. (2015). To see, or not to see? Rifted margin extension. Geology 43, 967-970. doi: 10.1130/g36982.1

McKenzie, D. P. (1978). Some remarks on the development of sedimentary basins. Earth Planet. Sci. Lett. 40, 20-32. doi: 10.1016/0012-821X(78)90071-7

Mohriak, W. U., and Leroy, S. (2013). Architecture of rifted continental margins and break-up evolution: insights from the South Atlantic, North Atlantic and Red Sea-Gulf of Aden conjugate margins. Geol. Soc. Lond. Spec. Publ. 369, 497-535. doi: 10.1144/sp369.17

Muntener, O., Manatschal, G., Desmurs, L., and Pettke, T. (2010). Plagioclase peridotites in ocean-continent transitions: refertilized mantle domains generated by melt stagnation in the shallow mantle lithosphere. J. Petrol. 51, 255-294. doi: 10.1093/petrology/egp087

Mutter, J. C. (1993). Margins declassified. Nature 365, 393-394. doi: 10.1080/ 09592296.2017 .1420520 
Naliboff, J. B., Buiter, S. J. H., Péron-Pinvidic, G., Osmundsen, P. T., and Tetreault, J. (2017). Complex fault interaction controls continental rifting. Nat. Commun. 8:1179. doi: 10.1038/s41467-017-00904-x

Norcliffe, J. R., Paton, D. A., Mortimer, E. J., McCaig, A. M., Nicholls, H., Rodriguez, K., et al. (2018). Laterally confined volcanic successions (LCVS); recording rift-jumps during the formation of magma-rich margins. Earth Planet. Sci. Lett. 504, 53-63. doi: 10.1016/j.epsl.2018.09.033

Osmundsen, P. T., Peron-Pinvidic, G., Ebbing, J., Erratt, D., Fjellanger, E., Bergslien, D., et al. (2016). Extension, hyperextension and mantle exhumation offshore Norway: a discussion based on 6 crustal transects. Norwegian J. Geol. 96, 343-372. doi: 10.17850/njg96-4-05

Pérez-Gussinyé, M., Morgan, J. P., Reston, T. J., and Ranero, C. R. (2006). The rift to drift transition at non-volcanic margins: insights from numerical modelling. Earth Planet. Sci. Lett. 244, 458-473. doi: 10.1016/j.epsl.2006.01.059

Peron-Pinvidic, G., Manatschal, G., and Osmundsen, P. T. (2013). Structural comparison of archetypal Atlantic rifted margins: a review of observations and concepts. Mar. Pet. Geol. 43, 21-47. doi: 10.1016/j.marpetgeo.2013.02.002

Phillips, T. B., Jackson, C. A. L., Bell, R. E., Duffy, O. B., and Fossen, H. (2016). Reactivation of intrabasement structures during rifting: a case study from offshore southern Norway. J. Struct. Geol. 91, 54-73. doi: 10.1016/j.jsg.2016. 08.008

Picazo, S., Müntener, O., Manatschal, G., Bauville, A., Karner, G., and Johnson, C. (2016). Mapping the nature of mantle domains in Western and Central Europe based on clinopyroxene and spinel chemistry: evidence for mantle modification during an extensional cycle. Lithos 266-267, 233-263. doi: 10.1016/j.lithos.2016. 08.029

Pinto, V. H. G., Manatschal, G., Karpoff, A. M., Ulrich, M., and Viana, A. R. (2017). Seawater storage and element transfer associated with mantle serpentinization in magma-poor rifted margins: a quantitative approach. Earth Planet. Sci. Lett. 459, 227-237. doi: 10.1016/j.epsl.2016.11.023

Ranero, C. R., and Perez-Gussinye, M. (2010). Sequential faulting explains the asymmetry and extension discrepancy of conjugate margins. Nature 468, 294297. doi: 10.1038 /nature 09520

Regenauer-Lieb, K., Rosenbaum, G., and Weinberg, R. F. (2008). Strain localisation and weakening of the lithosphere during extension. Tectonophysics 458, 96-104. doi: 10.1016/j.tecto.2008.02.014

Reston, T. J. (2005). Polyphase faulting during the development of the west Galicia rifted margin. Earth Planet. Sci. Lett. 237, 561-576. doi: 10.1016/j.epsl.2005.06. 019

Reston, T. J. (2009). The structure, evolution and symmetry of the magma-poor rifted margins of the North and Central Atlantic: a synthesis. Tectonophysics 468, 6-27. doi: 10.1016/j.tecto.2008.09.002

Ros, E., Pérez-Gussinyé, M., Araújo, M., Thoaldo Romeiro, M., Andrés-Martínez, M., and Morgan, J. P. (2017). Lower crustal strength controls on melting and serpentinization at magma-poor margins: potential implications for the South Atlantic. Geochem. Geophys. Geosyst. 18, 4538-4557. doi: 10.1002/ 2017GC007212

Rotevatn, A., Jackson, C. A. L., Tvedt, A. B. M., Bell, R. E., and Blaekkan, I. (2018). How do normal faults grow? J. Struct. Geol. 125, 174-184. doi: 10.1016/j.jsg. 2018.08.005
Rowan, M. G. (2014). Passive-margin salt basins: hyperextension, evaporite deposition, and salt tectonics. Basin Res. 26, 154-182. doi: 10.1111/bre. 12043

Rupke, L. H., Schmid, D. W., Perez-Gussinye, M., and Hartz, E. (2013). Interrelation between rifting, faulting, sedimentation, and mantle serpentinization during continental margin formation-including examples from the Norwegian Sea. Gcube 14, 4351-4368. doi: 10.1002/ggge. 20268

Stica, J. M., Zalán, P. V., and Ferrari, A. L. (2014). The evolution of rifting on the volcanic margin of the Pelotas Basin and the contextualization of the ParanáEtendeka LIP in the separation of Gondwana in the South Atlantic. Mar. Pet. Geol. 50, 1-21. doi: 10.1016/j.marpetgeo.2013.10.015

Svensen, H., Planke, S., Malthe-Sørenssen, A., Jamtveit, B., Myklebust, R., Rasmussen Eidem, T., et al. (2004). Release of methane from a volcanic basin as a mechanism for initial Eocene global warming. Nature 429:542. doi: 10.1038/ nature 02566

Unternehr, P., Peron-Pinvidic, G., Manatschal, G., and Sutra, E. (2010). Hyperextended crust in the south Atlantic: in search for a model. Pet. Geosci. 16 207-215. doi: 10.1144/1354-079309-904

van Wijk, J. W., van der Meer, R., and Cloetingh, S. (2004). Crustal thickening in an extensional regime: application to the mid-Norwegian Voring margin. Tectonophysics 387, 217-228. doi: 10.1016/j.tecto.2004.07.049

Wernicke, B. (1985). Uniform-sense normal simple shear of the continental lithosphere. Can. J. Earth Sci. 22, 108-125. doi: 10.1139/ e85-009

Whitmarsh, R. B., Manatschal, G., and Minshull, T. A. (2001). Evolution of magma-poor continental margins from rifting to seafloor spreading. Nature 413, 150-154. doi: 10.1038/35093085

Yang, L., Ren, J., McIntosh, K., Pang, X., Lei, C., and Zhao, Y. (2018). The structure and evolution of deepwater basins in the distal margin of the northern South China Sea and their implications for the formation of the continental margin. Mar. Pet. Geol. 92, 234-254. doi: 10.1016/j.marpetgeo.2018. 02.032

Zwaan, F., Schreurs, G., and Adam, J. (2018). Effects of sedimentation on rift segment evolution and rift interaction in orthogonal and oblique extensional settings: insights from analogue models analysed with 4D X-ray computed tomography and digital volume correlation techniques. Glob. Planet. Change 171, 110-133. doi: 10.1016/j.gloplacha.2017.11.002

Conflict of Interest Statement: The authors declare that the research was conducted in the absence of any commercial or financial relationships that could be construed as a potential conflict of interest.

Copyright (C) 2019 Peron-Pinvidic, Manatschal and the "IMAGinING RIFTING" Workshop Participants. This is an open-access article distributed under the terms of the Creative Commons Attribution License (CC BY). The use, distribution or reproduction in other forums is permitted, provided the original author(s) and the copyright owner(s) are credited and that the original publication in this journal is cited, in accordance with accepted academic practice. No use, distribution or reproduction is permitted which does not comply with these terms. 


\section{APPENDIX}

\section{The "IMAGinING RIFTING" Workshop Participants}

\begin{tabular}{|c|c|c|c|}
\hline Name & & E Mail & Affiliation \\
\hline Andersen & Torgeir & t.b.andersen@geo.uio.no & University of Oslo \\
\hline Autin & Julia & autin@unistra.fr & University of Strasbourg \\
\hline Ball & Philip & philip.ball@aramco.com & Aramco \\
\hline Brune & Sascha & brune@gfz-potsdam.de & GFZ German Research Centre for Geosciences \\
\hline Cadenas & Patricia & p.cadenas@unistra.fr & University of Strasbourg \\
\hline Cresswell & Derren & d.j.cresswell@bham.ac.uk & University of Birmingham \\
\hline Epin & Marie Eva & meepin@unistra.fr & University of Strasbourg \\
\hline Gómez-Romeu & Júlia & j.gomez-romeu@mandu-geology.fr & M\&U \\
\hline Gouiza & Mohamed & M.Gouiza@leeds.ac.uk & University of Leeds \\
\hline Harkin & Caroline & sgcharki@student.liverpool.ac.uk & University of Liverpool \\
\hline Jolivet & Laurent & laurent.jolivet@upmc.fr & ISTEP UPMC Paris \\
\hline Katz & Richard & richard.katz@earth.ox.ac.uk & University of Oxford \\
\hline Lescoutre & Rodolphe & rodolphe.lescoutre@unistra.fr & University of Strasbourg \\
\hline Lymer & Gael & gael.lymer@icrag-centre.org & iCRAG University College Dublin \\
\hline Magee & Craig & c.magee@leeds.ac.uk & University of Leeds \\
\hline Manatschal & Gianreto & manat@unistra.fr & University of Strasbourg \\
\hline Masini & Manu & mandu.geology@gmail.com & M\&U \\
\hline Miro & Jordi & jmiro@ub.edu & Universitat de Barcelona \\
\hline Molnar & Nicolas & nicolas.molnar@monash.edu & Monash University \\
\hline Mouthereau & Frederic & frederic.mouthereau@gmail.com & University of Toulouse \\
\hline Muntener & Othmar & othmar.muntener@unil.ch & University of Lausanne \\
\hline Ramos & Adrià & adria_ramos@outlook.com & $\begin{array}{l}\text { 1-Institut de Recerca Geomodels, Departament de } \\
\text { Dinàmica de la Terra i de l'Oceà, Universitat de Barcelona } \\
\text { 2-Terractiva Consulting SL }\end{array}$ \\
\hline Ranero & Cesar & cranero@cmima.csic.es & Instituto de Ciencias del Mar, CSIC \\
\hline Reston & Tim & T.J.Reston@bham.ac.uk & University of Birmingham \\
\hline Ribes & Charlotte & cribes@unistra.fr & University of Strasbourg \\
\hline Rooney & Tyrone & rooneyt@msu.edu & Michigan State University \\
\hline Rowan & Mark & mgrowan@frii.com & Rowan Consulting \\
\hline Snidero & Marco & marcosnidero@gmail.com & Universitat de Barcelona \\
\hline Tugend & Julie & julie.tugend@sorbonne-universite.fr & ISTeP, Sorbonne Université, Paris \\
\hline Wang & Lijie & ljwang@scsio.ac.cn & $\begin{array}{l}\text { CAS Key Laboratory of Ocean and Marginal Sea Geology, } \\
\text { South China Sea Institute of Oceanology }\end{array}$ \\
\hline Zwaan & Frank & frank.zwaan@geo.unibe.ch & formerly: University of Bern, currently: University of Florence \\
\hline
\end{tabular}

